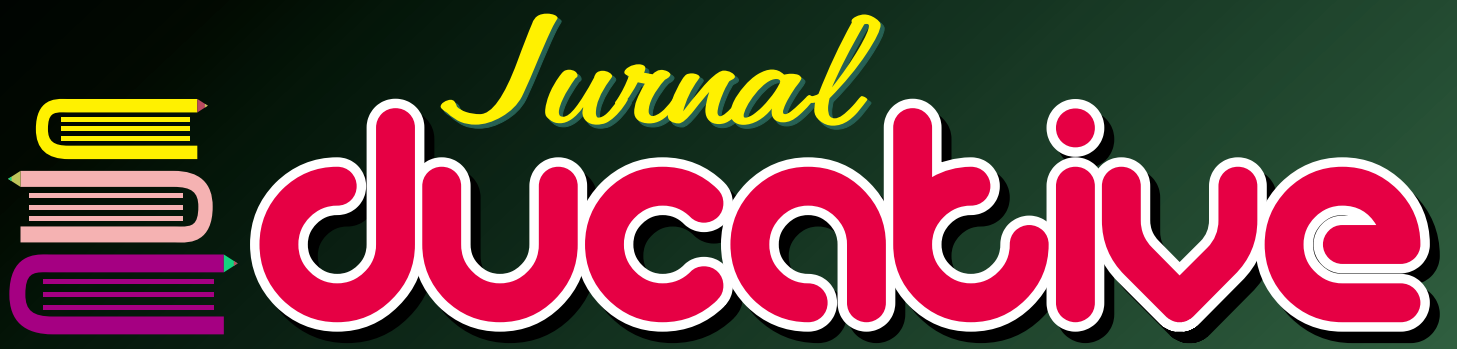 Journal of Educational Studies
}

Pengembangan Bahan Ajar Menulis Ringkasan dan Ikhtisar pada Mata Kuliah Pengembangan Keterampilan Menulis FKIP Universitas Baturaja Muhamad Doni Sanjaya, Muhamad Rama Sanjaya Upaya Meningkatkan Kemampuan Guru Menerapkan Penggunaan Bahan Ajar di SMA Negeri 3 Ogan Komering Ulu Aryanti Agustina

The Islamic Education Strategies Inlocal Culture Perspective of West Sumatera Society

Zulfani Sesmiarni, Junaidi, Darul Ilmi, Wedra Aprison

Problems In Learning Reading

(Case Study: Islamic Banking Students of IAIN Bukittinggi) Widya Syafitri

Teori Laactract dalam Persahabatan Generasi Millenial Qolbi Khoiri

e-Modul Computer Based Learning sebagai e-Resource Digital Literacy bagi Mahasiswa

Novrianti, Nofri Hendri, Ulfia Rahmi

Pengembangan Media Pembelajaran Mobile Learning berbasis Android Pada Mata Kuliah Kecerdasan Buatan Agus Nur Khomarudin, Liza Efriyanti

Meningkatkan Hasil Belajar Siswa Menggunakan Model Make a Match pada Mata Pelajaran IPS Kelas IV di SDN 11 OKU Yelmi Yunarti 


\title{
PENGEMBANGAN BAHAN AJAR MENULIS RINGKASAN DAN IKHTISA PADA MATA KULIAH PENGEMBANGAN KETERAMPILAN MENULIS FKIP UNIVERSITAS BATURAJA
}

\author{
Muhamad Doni Sanjaya ${ }^{1}$ \\ Program Studi Pendidikan Bahasa, Sastra Indonesia dan Daerab \\ Fakultas Keguruan dan Imu Pendidikan Universitas Baturaja \\ E-mail:donireni837@gmail.com
}

Muhamad Rama Sanjaya ${ }^{2}$

Program Studi Pendidikan Bahasa, Sastra Indonesia dan Daerah

Fakultas Keguruan dan Imu Pendidikan Universitas Baturaja

E-mail: sanjavamubamadrama@gmail.com

Diterima : 19 Maret 2018

Direvisi : 23 Mei 2018

Diterbitkan : 30 Juni 2018

\begin{abstract}
Absract
This study aims to (1) describe the need for text book in writing learning that's become as the development of instructional material, (2) produce textbooks that fit the needs analysis ofstudents, (3) describes the potential effects of textbook summaries and overviews of learning outcomes. This study is a research and development. Subjects in this study were students of Language, Literature Indonesian and Regional, the Faculty of Teacher Training and Education, University of Baturaja. The results show that Summary Writing and Summary textbooks of these development outcomes have a potential influence inimproving students' ability and understanding of writing materials.
\end{abstract}

Keywords: Development, Textbooks, Writing, Teaching Materials.

\section{Abstract}

Penelitian ini bertujuan untuk (1) mendeskripsikan kebutuhan buku teks dalam pembelajaran menulis yang dijadikan bahan ajar pengembangan, (2) menghasilkan buku teks yang sesuai dengan analisis kebutuhan mahasiswa, (3) mendeskripsikan efek potensial buku teks ringkasan dan ikhtisar terhadap hasil belajar. Penelitian ini merupakan penelitian dan pengembangan. Subjek dalam penelitian ini adalah mahasiswa Program Studi Pendidikan Bahasa, Sastra Indonesia dan Daerah Fakultas Keguruan dan Ilmu Pendidikan Universitas Baturaja. Hasil penelitian menunjukkan bahwa buku teks Menulis Ringkasan dan Ikhtisar hasil pengembangan ini mempunyai pengaruh potensial dalam meningkatkan kemampuan dan pemahaman mahasiswa terhadap materi-materi menulis.

Kata Kunci: Pengembangan, Buku Teks, Menulis, Bahan Ajar.

\section{Latar Belakang}

Keterampilan menulis merupakan salah satu mata kuliah yang diajarkan di perguruan tinggi khususnya Program Studi Pendidikan Bahasa, Sastra Indonesia dan Daerah Universitas Baturaja. Keterampilan ini secara intensif baru diberikan kepada mahasiswa semester dua (II). Mahasiswa terlebih dahulu diperkenalkan dengan mata kuliah "Dasar-
Dasar Menulis". Setiap selesai pemberian penjelasan teori, mereka berlatih langsung berbagai macam penulisan seperti ringkasan dan ikhtisar. Pelatihan ini dilakukan secara bertahap.

Di era globalisasi sekarang ini, sangat dibutuhkan generasi muda yang berintelektual. Maraknya ilmu pengetahuan dan teknologi, menyebabkan kita dengan secara tidak 
langsung ikut serta dalam pengembangan negara untuk menjadi negara yang lebih maju atau negara berkembang. Maka dari itu, kita harus meningkatkan generasi muda yang cinta akan membaca buku. Dengan begitu dapat meningkatkan pengetahuan, sehingga tercipta generasi yang berintelek. Salah satu solusi dalam hal ini ialah meningkatkan minat baca generasi dengan adanya pembuatan ringkasan maupun ikhtisar dari sebuah buku atau karangan ilmiah lainnya. Dengan adanya ringkasan, dan ikhtisar mereka akan tertarik untuk membaca buku tanpa harus membaca terlebih dahulu isi dari keseluruhan buku atau karangan ilmiah tersebut (Alex, 2011:122). ${ }^{1}$

Adapun tujuan dari pembuatan ikhtisar dan ringkasan ini adalah sebagai suatu usaha bagaimana cara meningkatkan minat pembaca dalam membaca buku atau karangan ilmiah lainnya, karena dengan begitu dapat meningkatkan pengetahuan mereka. Menulis ikhtisar dan ringkasan dari sebuah buku atau karangan yang panjang dapat diumpamakan sebagai memangkas pohon sehingga tinggal batang, cabang-cabang, dan ranting-ranting yang terpenting beserta daun-daun yang diperlukan, sehingga tampak esensi pohon masih dipertahankan. Walaupun bentuknya ringkas, namun tetap mempertahankan pikiran pengarang dan pendekatan yang asli (Alex, 2011:122).

Berdasarkan uraian di atas, pengembangan buku teks ini dilatarbelakangi oleh fenomena masih banyaknya mahasiswa yang peneliti temui, mereka mengalami kesulitan dalam menulis atau membuat ringkasan dan ikhtisar dari sebuah buku atau karangan ilmiah lainnya, masih menganggap kegiatan menulis adalah hal yang paling sukar, menjemukan, dan membosankan. Tanpa mereka sadari, sebenarnya membuat ringkasan dan ikhtisar itu tidak sesulit yang mereka pikirkan. Berdasarkan uraian tersebut maka diperlukan latihan dalam membuat ringkasan dan ikhtisar yang merupakan suatu cara yang sangat berguna untuk mengembangkan ekspresi serta penghematan kata. Latihan-

\footnotetext{
${ }^{1}$ Alex, Bahasa Indonesia Untuk Perguruan Tinggi (Jakarta: Kencana, 2011), h. 122-128
}

latihan yang intensif akan mengembangkan daya kreasi dan konsentrasi, serta mempertajam kemungkinan pemahaman karya, sehingga karya ringkasan dan ikhtisar itu tampaknya seolah-olah pematangan dalam diri penulis ringkasan dan ikhtisar itu. Suatu ringkasan dan ikhtisar yang cermat dan teliti tidak akan diperoleh tanpa mempelajari dengan cermat serta memahami apa yang dibaca atau didengar dengan menggunakan beberapa langkah-langkah untuk membuatnya menjadi lebih mudah. Maka dari itu, peneliti memilih judul "Pengembangan Bahan Ajar Menulis Ringkasan dan Ikhtisar Pada Mata Kuliah Pengembangan Keterampilan Menulis Semester II Program Studi Pendidikan Bahasa, Sastra Indonesia dan Daerah FKIP Universitas Baturaja.

\section{Kajian Literatur \\ PengertianBahan Ajar}

Bahan ajar merupakan sebuah susunan atas bahan-bahan yang berhasil dikumpulkan dan berasal dari berbagai sumber belajar yang dibuat secara sistematis (Prastowo, 2011:28). Bagaimana mungkin proses pembelajaran dapat berlangsung tanpa adanya bahan ajar yang disajikan kepada pembelajar. Apabila salah satu sistem itu tidak dihadirkan, maka akan mengganggu kelancaran sistem yang lainnya.

Menurut Ahmadi (2010:159) "Bahan ajar adalah segala bentuk bahan yang digunakan untuk membantu guru/instruktur dalam melaksanakan kegiatan belajar mengajar di kelas. Bahan yang dimaksud bisa berupa bahan tertulis maupun bahan tidak tertulis". Selanjutnya menurut Pannen (dikutip Setiawan, 2007:1.5) "Bahan ajar adalah bahan atau materi pelajaran yang disusun secara sistematis, yang digunakan guru dan siswa dalam proses pembelajaran". ${ }^{2}$

Berdasarkan pendapat di atas dapat disimpulkan bahwa bahan ajar adalah segala bentuk bahan atau materi yang disusun untuk membantu guru dalam proses pembelajaran.

2 Abu Ahmadi, Konstruksi Pengembangan Pembelajaran (Jakarta: Prestasi Pustaka, 2010), h. 159 


\section{Pengembangan Bahan Ajar}

Pengembangan bahan ajar merupakan wujud pengembangan strategi pembelajaran yang sesuai dengan prinsip-prinsip tertentu yang diadaptasi dari teori-teori pembelajaran (Syahid, 2003:17). Lebih lanjut, Syahid menjelaskan bahwa pengembangan bahan ajar ini bukan hanya didasarkan atas kepentingan pengembang, melainkan merupakan alternatif pemecahan masalah pembelajaran. Siswa bukan hanya berinteraksi dengan guru, melainkan juga dapat berinteraksi dengan sumber belajar yang digunakan untuk mencapai hasil yang diinginkan.

Mbulu (2004:6) menyatakan "ada empat tujuan pengembangan bahan ajar, yaitu: (1) diperolehnya bahan ajar yang sesuai dengan tujuan institusional, tujuan kurikuler, dan tujuan pembelajaran, (2) tersusunnya bahan ajar sesuai struktur isi mata pelajaran dengan karakteristiknya masing-masing, tersintesiskan dan terurutkannya topik-topik mata pelajaran secara sistematis dan logis, dan (4) terbukanya peluang pengembangan bahan ajar secara kontinu mengacu pada perkembangan Iptek". 3

Pengembangan bahan ajar harus didasarkan pada prinsip-prinsip tertentu agar tujuan di atas dapat diwujudkan. Menurut Amri dan Ahmadi, (2010:159) prinsip-prinsip dalam pemilihan dan pengembangan bahan ajar meliputi: (1) prinsip relevansi, (2) prinsip konsistensi, dan (3) prinsip kecukupan.

\section{Buku Sebagai Bahan Ajar}

Jenis bahan ajar cetak, selain bandout dan modul, adalah buku teks pelajaran. Menurut Nasution (dikutip Prastowo, 2011:165), "Buku teks pelajaran adalah bahan pengajaran yang paling banyak digunakan diantara semua bahan pengajaran lainnya". Sementara dalam kamus Oxford, buku diartikan sebagai number of sheet of paper, either printed or blank, fastened together in a cover, yaitu sejumlah lembaran kertas, baik cetakan maupun kosong, yang dijilid dan diberi kulit. Hal serupa juga dapat ditemukan dalam Kamus Besar Bahasa

\footnotetext{
${ }^{3}$ Mbulu, Pengembangan Bahan Ajar. (Malang: Elang Mas), h. 6
}

Indonesia yang mendefinisikan buku sebagai lembar kertas yang berjilid, berisi tulisan atau kosong (Setiawan, dikutip Prastowo, 2011:166).

Buku teks pelajaran tersusun atas beberapa komponen tertentu. Susunan komponen-komponen ini juga disebut sebagai struktur buku teks. Prastowo (2011:172) menyatakan "Bahan ajar berbentuk buku teks pelajaran terdiri atas lima komponen, yaitu: (1) Judul; (2) Kompetensi dasar atau materi pokok; (3) Informasi pendukung; (4) Latihan; (5) Penilaian. Jadi, dalam membuat sebuah buku teks pelajaran, maka kelima komponen utama itu harus ada. Selain itu, isi kandungannya juga harus mengacu kepada kompetensi dasar yang telah ditetapkan berdasarkan kurikulum yang berlaku".

\section{Pengertian Menulis}

$$
\text { Sebagai alat komunikasi dan }
$$
pengendali sosial, bahasa meliputi aneka ragam fungsi terapan, yang tentu saja tidak semuanya dapat diterima sebagai seni sastra. Bahasa dalam kehidupan sehari-hari dipergunakan dalam banyak hal seperti memerintah, bertanya, menginformasikan berita, laporan dan sebagainya (Jabrohim, 2009:9) ${ }^{4}$. Pada hakekatnya menulis merupakan suatu keterampilan berbahasa yang aktif, produktif, kompleks, dan terpadu yang berupa pengungkapan dan yang diwujudkan secara tertulis. Menulis juga merupakan keterampilan yang menuntut penulis untuk menguasai berbagai unsur di luar kebahasaan itu sendiri yang akan menjadi isi dalam suatu tulisan (Nurgiyantoro, 2001:271).

$$
\text { Sementara Yunus }{ }^{5} \quad \text { (2002:13), }
$$
menyatakan "Menulis merupakan kegiatan komunikasi verbal yang berisi penyampaian pesan dengan menggunakan tulisan sebagai mediumnya". Dengan demikian, menulis merupakan suatu keterampilan berbahasa yang dipergunakan untuk berkomunikasi secara

4 Jabrohim, Cara Menulis Kreatif. (Yogyakarta: Pustaka Pelajar), h. 9

5 9M. Yunus, Surat Menyurat Dinas dalam Keterampilan Dasar Menulis Modul. Jakarta: Universitas Terbuka), h. 13 
tidak langsung tidak secara tatap muka dengan orang lain (Simulyasi, 2015:65)

Berdasarkan beberapa pendapat tersebut dapat disimpulkan bahwa menulis adalah suatu kegiatan komunikasi verbal yang berisi informasi dengan melibatkan aktivitas otak kanan dan otak kiri dengan tulisan sebagai wahana mediumnya.

\section{Pengertian/ Perbedaan Ringkasan dan Ikhtisar}

Ringkasan merupakan hasil kegiatan meringkas atau merangkum. Ringkasan dapat diartikan sebagai suatu hasil merangkum atau meringkas suatu tulisan atau pembicaraan menjadi suatu uraian yang lebih singkat dengan perbandingan secara proporsional antara bagian yang dirangkum dengan rangkumannya (Husnul, 2010:38) ${ }^{6}$. Sementara menurut Alex (2011:124) "Ringkasan merupakan penyajian singkat suatu karangan asli, sedangkan perbandingan bagian atau bab dari karangan asli secara proporsional tetap dipertahankan dalam bentuknya yang singkat".

Menurut Desrina (2013:48) ringkasan berarti merangkum bahan yang panjang menjadi sedikit mungkin. Namun yang sedikit itu dapat mewakili atau menjelaskan yang panjang. Jadi, secara umum dapat disimpulkan bahwa tujuan meringkas adalah memahami dan mengetahui isi sebuah buku atau karangan.

Ringkasan sering disebut juga rangkuman, yaitu bentuk ringkas dari suatu uraian atau pembicaraan. Pada tulisan jenis ringkasan, urutan isi bagian demi bagian, dan sudut pandang (pendapat) pengarang tetap diperhatikan dan dipertahankan. Sementara ikhtisar merupakan bentuk ringkas dari suatu uraian atau pembicaraan, namun dalam pembuatannya tidak perlu mempertahankan urutan isi dari suatu karangan secara proporsional. Penulisan ikhtisar bisa saja langsung tertuju pada pokok permasalahan (Husnul, 2010:38). Di sisi lain Alex (2011:122) menyatakan "Ikhtisar adalah penulisan pokok-

6 Ade Husnul, Cermat Menulis Ikhtisar dan Ringkasan Isi Buku. (Bogor: Quadra), h. 38-39 pokok masalah yang penulisannya tidak harus berurutan, boleh secara acak atau disajikan dalam bahasa pembuat ikhtisar tanpa mengubah tema sebuah wacana".

Berdasarkan pendapat para ahli di atas, maka dapat disimpulkan bahwa definisi dari ringkasan adalah bentuk ringkas dari suatu uraian atau pembicaraan atau bab dari karangan asli secara proporsional tetap dipertahankan dalam bentuknya yang singkat. Sementara ikhtisar adalah merupakan bentuk ringkas dari suatu uraian atau pembicaraan, namun dalam pembuatannya tidak perlu mempertahankan urutan isi dari suatu karangan secara proporsional.

\section{Cara Membuat Ringkasan dan Ikhtisar}

Menurut Alex (2011:125-128) ada
beberapa pegangan yang digunakan untuk membuat ringkasan yang baik dan teratur sebagai berikut : a) Membaca karangan asli; b) Mencatat Gagasan Utama; c) Mengadakan Reproduksi; d) Ketentuan Tambahan.

Sementara cara untuk membuat ikhtisar sebagai berikut : a) Membaca naskah asli beberapa kali (setidak-tidaknya dua kali); b) Membuat kerangka bacaan dengan menuliskan pikiran utama atau pikiran pokok yang terdapat dalam naskah; c) Menuliskan ikhtisar (Alex, 2011: 124).

Sejalan dengan pendapat di atas (Husnul, 2010: 39) menyatakan ada beberapa langkah yang harus dilakukan dalam membuat ikhtisar, diantaranya: a) Perangkum harus membaca uraian asli pengarang sampai tuntas; b) Perangkum membaca kembali bacaan yang akan dirangkum dengan membuat catatan pikiran utama atau menandai pikiran utama setiap uraian untuk setiap bagian atau setiap parangraf; c) Dengan berpedoman hasil catatan, perangkum mulai membuat rangkuman dan menyusun kalimat-kalimat yang bertolak dari hasil catatan dengan menggunakan bahasa perangkum sendiri; d) Perangkum perlu membaca kembali hasil rangkuman dan mengadakan perbaikan apabila dirasa ada kalimat yang kurang koheren.; e) Perangkum perlu menulis kembali hasil rangkumannya berdasarkan hasil perbaikan 
dan memastikan bahwa rangkuman yang dihasilkan lebih pendek dibanding dengan bacaan yang dirangkum.

\section{Metodologi Penelitian Metode Penelitian}

Penelitian ini menggunakan metode penelitian dan pengembangan (Research and Development). Metode penelitian dan pengembangan digunakan untuk menghasilkan bahan ajar tertentu berbentuk buku teks dan menguji keefektifan produk tersebut. Tujuan penelitian ini adalah untuk mengembangkan produk bahan ajar yang efektif digunakan oleh mahasiswa semester II Program Studi Pendidikan Bahasa, Sastra Indonesia dan Daerah khususnya di Universitas Baturaja. Bahan ajar yang dikembangkan adalah bahan ajar berbentuk buku teks yaitu Menulis Ringkasan dan Ikbtisar.

\section{Pendekatan Pengembangan}

Pendekatan pengembangan bahan ajar yang digunakan dalam penelitian ini menggunakan pendekatan model Jolly dan Bolitho. Prosedur dalam penelitian ini dilakukan melalui tiga tahap yaitu tahap identifikasi dan pengembangan, tahap validasi, dan tahap uji lapangan. Adapun perincian tahap tersebut sebagai berikut.

Tahap Identifikasi dan Pengembangan terdiri dari : 1) Identifikasi kebutuhan bahan ajar. Pada tahap ini, peneliti melakukan analisis kebutuhan bahan ajar guru dan siswa yang berkaitan dengan kesulitan dan kendalakendala yang dihadapi guru dan siswa serta harapan-harapan guru dan siswa terhadap bahan ajar yang dikembangkan. Analisis kebutuhan ini menggunakan angket; 2) Eksplorasi kebutuhan. Pada tahap ini peneliti melakukan observasi silabus mata kuliah Pengembangan Keterampilan Menulis terutama materi Ringkasan dan Ikbtisar dan buku sumber yang digunakan oleh dosen dan mahasiswa pada pembelajaran menulis; 3) Realisasi kontekstual bahan ajar. Pada tahap ini, peneliti mengembangkan bahan ajar Menulis Ringkasan dan Ikbtisar dengan melakukan analisis tujuan dan karakteristik materi, analisis sumber belajar, analisis karakteristik pembelajar. Bahan ajar tersebut dilengkapi dengan contoh-contoh, latihan, rangkuman, evaluasi, dan glosarium yang melibatkan pengalaman belajar mahasiswa sesuai dengan tujuan pembelajaran. 4) Realisasi pedagogik bahan ajar. Pada tahap ini pengembangan bahan ajar Menulis Ringkasan dan Ikbtisar dengan menetapkan strategi pengorganisasian isi pembelajaran, menetapkan strategi penyampaian isi pembelajaran dan menetapkan strategi pengelolaan pembelajaran. 5) Produksi bahan ajar. Pada tahap ini, peneliti mengembangkan bahan ajar yang efektif dan memproduksinya dalam bentuk buku teks untuk mahasiswa. Bahan ajar tersebut memiliki karakteristik yaitu memuat: (a) judul, (b) petunjuk belajar untuk dosen dan mahasiswa, (c) kompetensi dasar/materi pokok (d) informasi pendukung, (e) latihan-latihan, (f) rangkuman, (g) penilaian, (h) glosarium, dan (i) daftar pustaka.

Tahap Validasi Ahli terdiri dari : 1) Validasi ahli diberikan kepada 4 orang ahli yaitu (a) Ahli bidang materi (content) untuk menilai kebenaran dan kesesuaian materi dalam bahan ajar. (b) Ahli bahasa (language) untuk menilai keefektifan bahasa serta ketepatan tingkat keterbacaan bahan ajar. (c) Ahli penyajian untuk menilai kejelasan dan kelengkapan bahan ajar yang dikembangkan. (d) Ahli kegrafikaan untuk menilai kegrafikaan (desain gambar, cover, atau ilustrasi) yang digunakan dalam bahan ajar hasil pengembangan; 2) Revisi bahan ajar. Berdasarkan hasil validasi ahli, peneliti akan merevisi bahan ajar berbentuk buku teks berdasarkan informasi dan masukan dari validasi ahli.

Tahap Uji Coba Lapangan meliputi : 1) Penggunaan bahan ajar oleh mahasiswa. Bahan ajar hasil pengembangan akan diberikan pada mahasiswa untuk digunakan dalam pembelajaran menulis di kelas; 2) Ujicoba lapangan. Pada tahap ini, peneliti melakukan uji coba lapangan (field trial) pada sekelompok mahasiswa (1 kelas atau sebanyak 23 orang mahasiswa) untuk melihat efek potensial bahan ajar yang telah dikembangkan oleh peneliti. 


\section{Lokasi Penelitian}

Penelitian ini dilakukan di Program Studi Pendidikan Bahasa, Sastra Indonesia dan Daerah FKIP Universitas Baturaja yang berada di Jalan Ratu Penghulu Karang Sari No. 02301 Baturaja Sumatera Selatan.

\section{Teknik Pengumpulan Data}

Teknik pengumpulan data yang digunakan dalam penelitian ini adalah angket dan tes. Angket tersebut diberikan kepada mahasiswa dan dosen. Tujuannya untuk menjaring data identifikasi kebutuhan mahasiswa dan dosen tentang bahan ajar yang akan dikembangkan peneliti. Angket tersebut berisi tentang kebutuhan mahasiswa dan dosen mengenai bentuk bahan ajar, kegiatan belajar, materi pembelajaran, strategi, metode pembelajaran, evaluasi, serta latihan yang diinginkan oleh mahasiswa dan dosen.

Selanjutnya, angket juga diberikan kepada ahli yaitu (1) kelayakan isi, (2) kebahasaan, (3) penyajian, dan (4) kegrafikaan. Sementara itu, tes diberikan kepada mahasiswa berupa tesuraian, yaitu berupa soal yang mengacu pada isi bacaan yang telah dibacanya dalam bentuk menulis ringkasan dan ikhtisar. Tes ini diberikan sebelum dan setelah mahasiswa membaca dan mempelajari buku teks hasil pengembangan peneliti.

\section{Hasil Penelitian dan Pembahasan \\ Identifikasi Kebutuhan Mahasiswa}

Identifikasi kebutuhan terhadap mahasiswa semester II Program Studi Pendidikan Bahasa, Sastra Indonesia dan Daerah Universitas Baturaja bertujuan untuk menjaring data tentang kebutuhan mahasiswa isi bahan ajar yang dikembangkan peneliti. Hal ini didasari oleh pendapat Richterich (dikutip Nunan, 1992:44), bahwa kebutuhan mahasiswa adalah kebutuhan subjektif. Kebutuhan subjektif merupakan kebutuhan yang ditentukan sendiri oleh mahasiswa sebagai subjek yang akan belajar.

Untuk mengidentifikasi kebutuhan mahasiswa, pada tanggal 7 Agustus sampai 31 Agustus 2016 peneliti menyebarkan angket terbuka kepada 23 subjek penelitian pada semester II Program Studi Pendidikan Bahasa, Sastra Indonesia dan Daerah Universitas Baturaja. Subjek penelitian dikumpulkan di ruang kelas 10 Program Studi Pendidikan Bahasa, Sastra Indonesia dan Daerah Universitas Baturaja. Lalu subjek penelitian diberikan penjelasan tentang tata cara pengisian angket tersebut.

Aspek-aspek yang dijadikan sebagai dasar informasi kebutuhan mahasiswa tersebut terhadap bahan ajar Menulis Ringkasan dan Ikhtisar mahasiswa semester II Program Studi Pendidikan Bahasa, Sastra Indonesia dan Daerah Universitas Baturaja yang berjudul Mari Menulis Ringkasan dan Ikbtisar terdapat 10 aspek. Adapun aspek-aspek tersebut berkaitan dengan: (1) materi menulis ringkasan dan ikhtisar menyenangkan, (2) perwajahan buku teks menulis ringkasan dan ikhtisar, (3) tampilan fisik buku, (4) ilustrasi, (5) materi dalam pembelajaran menulis ringkasan dan ikhtisar, (6) bahasa, (7) tujuan pembelajaran, (8) strategi, (9) media pembelajaran, dan (10) evaluasi.

Berdasarkan hasil analisis kebutuhan mahasiswa terhadap bahan ajar Menulis Ringkasan dan Ikbtisar yang dikembangkan oleh peneliti melalui angket terbuka diketahui bahwa sebagian besar mahasiswa mengharapkan hal-hal berikut ini : 1) Terkait dengan materi menulis ringkasan dan ikhtisar mereka berpendapat menyenangkan karena dapat menambah wawasan dan pengetahuan. Oleh karena itu, bahan ajar tersebut harus menarik dilihat dari tampilan fisiknya yaitu ilustrasi dan perwajahannya; 2) Ilustrasinya berbentuk gambar atau bagan yang dapat memberikan daya tarik, dapat memotivasi; 3) Materi yang terdapat dalam bahan ajar tersebut terdiri dari teori-teori menulis dan kegiatan praktik menulis ringkasan dan ikhtisar; 4) Bahasa dalam bahan ajar tersebut menggunakan bahasa yang mudah dipahami; 5) Tujuan pembelajaran yang diinginkan dalam bahan ajar Menulis Ringkasan dan Ikbtisar harus sesuai dengan Standar Kompetensi dan Kompetensi Dasar; 6) Strategi yang diinginkan dalam bahan ajar Menulis Ringkasan dan Ikbtisar mereka menginginkan strategi yang banyak memberikan contoh-contoh dan praktik 
menulis; 7) Media yang diinginkan dalam bahan ajar Menulis Ringkasan dan Ikbtisar, harus menarik penuh dengan warna; 8) Evaluasi yang diharapkan dalam menulis ringkasan dan ikhtisar bersifat objektif dengan tugas dan latihan yang memberikan pengetahuan terutama menulis ringkasan dan ikhtisar.

\section{Identifikasi Kebutuhan Dosen}

Untuk mendapatkan informasi tentang kebutuhan dosen terhadap bahan ajar Menulis Ringkasan dan Ikhtisar yang berbentuk buku teks, peneliti melakukan identifikasi kebutuhan kepada dua orang dosen Program Studi Pendidikan Bahasa, Sastra Indonesia dan Daerah FKIP Universitas Baturaja. informasi kebutuhan dosen tersebut diperoleh melalui angket terbuka. Angket terbuka tersebut diberikan kepada dua orang dosen yang mengajar mata kuliah Pengembangan Keterampilan Menulis tentang Ringkasan dan Ikbtisar pada tanggal 7 Agustus sampai 31 Agustus 2016.

Aspek-aspek yang diidentifikasi dalam angket tersebut adalah sebagai berikut. (1) seberapa penting materi menulis ringkasan dan ikhtisar, (2) bentuk bahan ajar yang diinginkan, (3) sistematika pembelajaran, (4) tujuan pembelajaran, (5) topik-topik bahan ajar, (6) kegiatan belajar yang diharapkan, (7) strategi pembelajaran untuk mahasiswa, (8) metode yang sesuai dengan mahasiswa, (9) media pembelajaran, (10) evaluasi pembelajaran untuk materi menulis ringkasan dan ikhtisar, serta (11) saran yang diberikan dalam bahan ajar menulis ringkasan dan ikhtisar.

Berdasarkan analisis kebutuhan dosen terhadap bahan ajar Menulis Ringkasan dan Ikbtisar diperoleh sebagian besar dosen mengharapkan hal-hal berikut ini : 1) Bahan ajar Menulis Ringkasan dan Ikbtisar sangat penting dalam pembelajaran menulis ringkasan dan ikhtisar, oleh sebab itu bahan ajar yang digunakan dalam pembelajaran menulis ringkasan dan ikhtisar dapat disesuaikan dengan harapan dan keinginan mahasiswa; 2) Bentuk bahan ajar yang diinginkan bentuk buku teks, karena lebih mudah dipahami; 3) Sistematika bahan ajar tersebut terdapat judul, petunjuk belajar, kompetensi dasar, informasi pendukung, latihan, evaluasi, rangkuman, glosarium, dan daftar pustaka; 4) Tujuan pembelajaran yang diinginkan dalam bahan ajar Menulis Ringkasan dan Ikbtisar harus disesuaikan dengan pemahaman mahasiswa; 4) Topik-topik bahan ajar Menulis Ringkasan dan Ikbtisar bersifat praktik; 5) Kegiatan belajar bahan ajar tersebut lebih banyak praktik menulis; 6) Strategi bahan ajar tersebut berbentuk demonstrasi langsung kepada mahasiswa; 7) Metodenya menggunakan ceramah dan kooperatif learning; 8) Media yang diinginkan berbentuk slide yang dilengkapi dengan contoh-contoh yang detail tentang suatu materi; 9) Bentuk evaluasi yang diinginkan dalam bahan ajar Menulis Ringkasan dan Ikbtisar berbentuk evaluasi tertulis; 10) Berkaitan dengan saran yang diberikan dalam bahan ajar Menulis Ringkasan dan Ikbtisar, perlu ditambah contoh-contoh dari menulis ringkasan dan ikhtisar.

\section{Prototipe Bahan Ajar}

Berdasarkan analisis identifikasi kebutuhan mahasiswa dan dosen dan bahan ajar yang digunakan, dikembangkan bahan ajar Menulis Ringkasan dan Ikbtisar yang diharapkan dapat membantu meningkatkan pemahaman menulis mahasiswa semester II Program Studi Pendidikan Bahasa, Sastra Indonesia dan Daerah Fakultas Keguruan dan Ilmu Pendidikan (FKIP), Universitas Baturaja. Proses menghasilkan bahan ajar dilakukan sesuai dengan langkah-langkah yang dikembangkan oleh Jolly dan Bolitho sebagaimana dikemukakan pada bab tiga.

Berdasarkan hasil identifikasi diperoleh informasi tentang kebutuhan mahasiswa dan dosen tidak jauh berbeda. Mahasiswa dan dosen membutuhkan bahan ajar Menulis Ringkasan dan Ikbtisar yang bersifat fleksibel agar dapat digunakan siapa saja yang membacanya, bahan ajar Menulis Ringkasan dan Ikhtisar yang dilengkapi petunjuk pembelajaran menulis, dan bahan ajar yang memiliki petunjuk penilaian (rubrik penilaian) untuk masing-masing kegiatan menulis, dengan tujuan mengurangi unsur subjektivitas dalam penilaian.

Setelah, peneliti melakukan analisis kebutuhan berupa angket terbuka yang 
diberikan kepada 50 orang mahasiswa dan 2 orang dosen, peneliti melakukan eksplorasi kebutuhan, realisasi kontekstual, dan realisasi pedagogik. Pada tahap eksplorasi kebutuhan bahan ajar, peneliti melakukan observasi terhadap silabus dan buku sumber yang digunakan oleh dosen dalam melaksanakan pembelajaran menulis ringkasan dan ikhtisar di kelas. Berdasarkan hasil pengamatan, silabus mata kuliah Pengembangan Keterampilan Menulis yang dirancang oleh dosen pengampu mata kuliah Pengembangan Keterampilan Menulis, meliputi materi-materi sebagai berikut. (1) menulis ringkasan, (2) menulis ikhtisar.

Pada penelitian dan pengembangan ini, peneliti hanya mengembangkan materi-materi menulis ringkasan dan menulis ikhtisar. Sementara itu, sumber bahan ajar yang dipergunakan mereka berbentuk buku teks. Oleh karena itu, bentuk bahan ajar dalam penelitian dan pengembangan ini berbentuk buku teks.

Selanjutnya, peneliti melakukan tahap realisasi kontekstual, dan realisasi pedagogik. Pada tahap realisasi kontekstual, peneliti melakukan analisis tujuan pembelajaran yang akan dicapai. Hasilnya, peneliti mengembangkan tujuan pembelajaran sesuai dengan menulis ringkasan dan ikhtisar. Pada materi ringkasan, tujuan pembelajaran yang dicapai adalah mahasiswa dituntut untuk dapat menuliskan ringkasan. Pada ikhtisar, tujuan pembelajaran yang dicapai yaitu, mahasiswa dituntut untuk dapat menuliskan ikhtisar.

Tahap selanjutnya adalah realisasi pedagogis yang diwujudkan dengan penyusunan petunjuk belajar, penetapan metode penyampaian materi, tugas-tugas, dan latihan yang disajikan dalam bahan ajar Menulis Ringkasan dan Ikbtisar hasil pengembangan. Sebagai latihan, mahasiswa diberi tugas membaca materi kemudian mengungkapkan isi yang terkandung dalam teks bacaan baik dalam bentuk uraian atau pilihan ganda.

Setelah tahap realisasi kontekstual dan pedagogis, tahap selanjutnya adalah produksi bahan ajar. Bahan ajar yang dihasilkan berupa buku teks. Sebelum buku teks Menulis Ringkasan dan Ikbtisar hasil pengembangan peneliti diujicobakan pada mahasiswa (subjek penelitian) Program Studi Pendidikan Bahasa, Sastra Indonesia dan Daerah FKIP, Universitas Baturaja (secara terbatas), dilakukan penilaian (validasi) terlebih dahulu oleh ahli. Adapun ahli tersebut adalah Arinah Fransori, M.Pd. (dosen Universitas Tridinanti Palembang Program Studi Pendidikan Bahasa ) yang menilai kelayakan materi/isi. Helaludin, M.Pd. (dosen Universitas Tridinanti Palembang Program Studi Pendidikan Bahasa) yang menilai penyajian, Arif Qosim, M.Pd. (dosen Program Studi Teknologi Pendidikan FKIP Unbara) yang menilai kegrafikaan, dan Awalludin, M.Pd. (dosen Program Studi Pendidikan Bahasa, Sastra Indonesia dan Daerah FKIP Unbara) yang menilai kebahasaan.

Bahan ajar yang dikembangkan oleh peneliti terdiri dari 3 bagian, yaitu bagian pendahuluan, bagian isi, dan bagian penutup. Bagian pendahuluan terdiri atas (1) sampul atau cover depan, (2) halaman judul atau cover dalam, (3) kata pengantar, dan (4) daftar isi. Bagian isi terdiri dari beberapa kegiatan pembelajaran yaitu meliputi: (1) judul, (2) petunjuk belajar untuk dosen dan mahasiswa, (3) kompetensi dasar/materi pokok, (4) informasi pendukung, (5) latihan-latihan, (6) rangkuman, (7) penilaian, (8) glosarium. Bagian penutup (1) daftar pustaka dan (2) cover belakang.

\section{Tahap Validasi Ahli}

Validasi ahli bahan ajar berupa buku teks Menulis Ringkasan dan Ikbtisar hasil pengembangan peneliti dilakukan mulai 1 November 2016 sampai dengan 7 November 2016. Validasi ahli tersebut terdiri dari ahli isi/materi, ahli bahasa, ahli penyajian, dan ahli kegrafikaan. Hasil validasi bahan ajar Menulis Ringkasan dan Ikbtisar hasil pengembangan peneliti adalah sebagai berikut.

\section{Kelayakan isi}

Berdasarkan hasil penilaian ahli kelayakan isi/materi yang dilaksanakan pada tanggal 1 November 2016 sampai dengan 2 November 2016 dari segi kelayakan isi materi bahan ajar Menulis Ringkasan dan Ikbtisar yang 
dikembangkan peneliti dikategorikan baik. Hal ini dilihat dari enam aspek penilaian dengan skala 5 validator memberikan skor rata-rata 23 . Oleh karena itu, secara keseluruhan dari skor maksimal 30, aspek kelayakan isi memperoleh skor 23. Artinya, kelayakan isi bahan ajar yang dikembangkan termasuk kategori baik. Meskipun bahan ajar sudah dikategorikan baik, terdapat beberapa saran dari ahli isi yang berkaitan dengan isi materi, indikator pencapaian, dan contoh teks bacaan serta rubrik penilaian setiap pembelajaran dalam bab.

Adapun saran-saran dari ahli materi adalah sebagai berikut. Bahan ajar tersebut sumber kutipan agar dicantumkan, petunjuk soal yang jelas, efektif dan komunikatif sehingga lebih mudah dipahami mahasiswa serta sistematika penulisan dan tanda baca agar diperhatikan.

\section{Kelayakan Bahasa}

Berdasarkan hasil penilaian ahli kebahasaan, yang dilaksanakan pada tanggal 1 November 2016 sampai dengan 3 November 2016, bahan ajar yang dikembangkan dapat dikategorikan baik. Dari empat aspek yang dinilai dengan penilaian skala 5, yaitu aspek keterbacaan memperoleh skor 15 dari skor maksimal 20. Artinya bahasa yang dipergunakan dalam prototipe bahan ajar Menulis Ringkasan dan Ikbtisar yang dikembangkan sudah baik. Akan tetapi validator memberikan beberapa saran terhadap bahasa dalam bahan ajar hasil pengembangan peneliti berkenaan dengan kesalahan penulisan kata dan penggunaan tanda baca.

\section{Kelayakan Penyajian/Sajian}

Berdasarkan hasil penilaian dari aspek penyajian/sajian isi bahan ajar Menulis Ringkasan dan Ikbtisar yang dilaksanakan pada tanggal 4 November 2016 sampai dengan 6 November 2016 dikategorikan baik. Dari lima aspek yang dinilai dengan penilaian skala 5, yaitu kejelasan tujuan pembelajaran, urutan penyajian, pemberian motivasi/daya tarik, interaktivitas, dan kelengkapan informasi memperoleh skor 17 dari skor maksimal 25 .
Artinya sajian bahan ajar dapat dikategorikan baik.

Adapun saran dari validator meliputi tujuan pembelajaran terlalu bersifat universal dan teoritis, latihan soal tidak sesuai dengan tujuan pembelajaran, materi yang dikemukakan harus selaras dengan tujuan pembelajaran, berikan contoh yang konkret dan pertimbangkan bahan ajar agar memberikan kemudahan bagi mahasiswa mencapai tujuan pembelajaran.

\section{Kelayakan Kegrafikaan}

Berdasarkan penilaian ahli dari aspek kegrafikaan yang dilaksanakan pada tanggal 5 November 2016 sampai dengan 7 November 2016 menunjukkan tampilan yang dapat dikategorikan sangat baik. Secara keseluruhan dari skor maksimal 25, aspek kegrafikaan memperoleh skor 22. Artinya, aspek kegrafikaan bahan ajar yang dikembangkan termasuk kategori sangat baik.

Beberapa saran dari penilai antara lain ukuran font untuk hal yang penting perlu diperbesar, judul dan subjudul diberi latar supaya lebih menarik.

\section{Tahap Uji Coba Lapangan}

Uji lapangan terbatas ini terdiri dari 23 orang mahasiswa semester II kelas A.2.1 Program Studi Pendidikan Bahasa, Sastra Indonesia dan Daerah FKIP Universitas Baturaja. Uji lapangan terhadap bahan ajar Menulis Ringkasan dan Ikhtisar dimaksudkan untuk mengukur kemampuan mahasiswa memahami materi menggunakan bahan ajar hasil pengembangan peneliti. Kemampuan mahasiswa memahami materi menulis ringkasan dan ikhtisar diukur melalui tes yaitu tes menulis dan menjawab pertanyaan dalam teks bacaan.

Untuk mengukur kemampuan mahasiswa tersebut, peneliti melakukan tes terhadap dua tahap, yaitu pretest dan posttest. Pretest dilaksanakan sebelum mahasiswa diberikan buku teks hasil pengembangan. Tes ini dilaksanakan pada tanggal 5 sampai 17 September 2016. Selanjutnya, posttest dilaksanakan sesudah mahasiswa diberikan 
buku teks hasil pengembangan berikut penjelasannya. Tes ini dilaksanakan pada tanggal 19 September 2016 sampai dengan 1 Oktober 2016. Adapun hasil tes yang diberikan terhadap mahasiswa A.2.1, Program Studi Pendidikan Bahasa, Sastra Indonesia dan Daerah, Fakultas Keguruan dan Ilmu Pendidikan, Universitas Baturaja adalah sebagai berikut.

\section{Hasil Pretest dan Posttest Menulis Ringkasan}

Hasil Pretest dan Posttest materi menulis ringkasan pada Program Studi Pendidikan Bahasa, Sastra Indonesia dan Daerah, Fakultas Keguruan dan Ilmu Pendidikan, Universitas Baturaja dapat dilihat pada tabel 1 berikut ini.

Tabel 1 Nilai Pretest dan Posttest Materi Menulis Ringkasan

\begin{tabular}{|c|c|c|c|}
\hline \multirow{2}{*}{ No } & \multirow{2}{*}{$\begin{array}{c}\text { Nama } \\
\text { Mahasiswa }\end{array}$} & \multicolumn{2}{|c|}{ Nilai } \\
\hline & & Pretest & Postest \\
\hline 1. & APR & 60 & 65 \\
\hline 2. & HNS & 70 & 80 \\
\hline 3. & LSH & 70 & 75 \\
\hline 4. & YIS & 65 & 70 \\
\hline 5. & $\mathrm{AAC}$ & 60 & 70 \\
\hline 6. & $\mathrm{NAO}$ & 70 & 80 \\
\hline 7. & PAR & 50 & 70 \\
\hline 8. & SUN & 50 & 60 \\
\hline 9. & ONS & 50 & 75 \\
\hline 10. & AKS & 65 & 85 \\
\hline 11. & AAD & 50 & 60 \\
\hline 12. & MSA & 60 & 80 \\
\hline 13. & ERD & 65 & 75 \\
\hline 14. & SFI & 70 & 75 \\
\hline 15. & NZP & 60 & 65 \\
\hline 16. & GOP & 70 & 75 \\
\hline 17. & HAR & 50 & 70 \\
\hline 18. & MSM & 50 & 75 \\
\hline 19. & BIR & 70 & 85 \\
\hline 20. & RAS & 70 & 80 \\
\hline 21. & NAS & 60 & 65 \\
\hline 22. & MMH & 50 & 65 \\
\hline 23. & MAS & 50 & 60 \\
\hline & Jumlah & 1395 & 1660 \\
\hline & Rata-rata & 60,65 & 72,17 \\
\hline & Selisih & & \\
\hline
\end{tabular}

Berdasarkan data nilai pretest dan posttest yang diperoleh dalam tes menulis ringkasan yang terdapat pada tabel tersebut, secara keseluruhan terlihat bahwa nilai yang diperoleh mahasiswa mengalami peningkatan. Nilai tertinggi pada kegiatan pretest sebelum mahasiswa menulis ringkasan adalah 70 . Setelah mahasiswa diberikan penjelasan dan menuliskan kembali ringkasan, nilai tertinggi mahasiswa mencapai 85. Sebaliknya, nilai terendah sebelum mahasiswa menuliskan ringkasan hanya mencapai nilai 50 dan setelah diberikan penjelasan dan menuliskan kembali ringkasan hasil pengembangan nilainya adalah 60. Adapun perincian perolehan nilai mahasiswa tersebut dapat digambarkan pada grafik berikut ini.

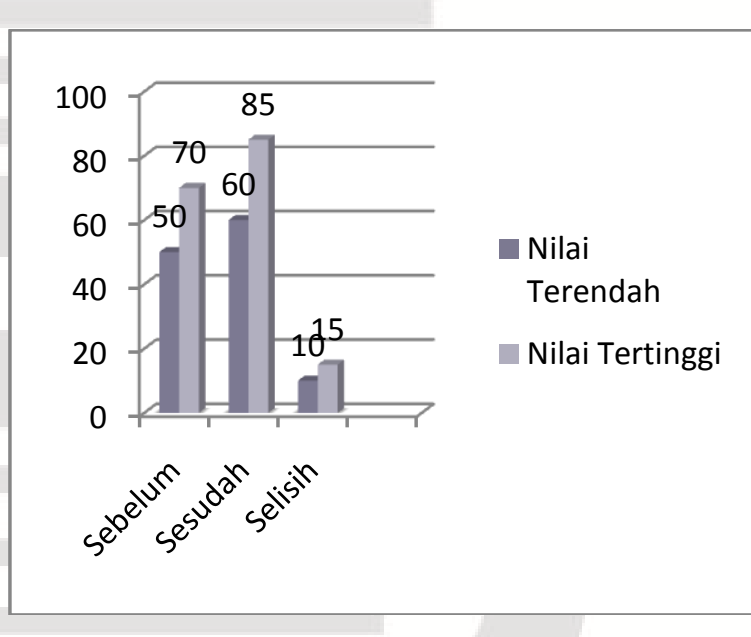

Grafik 1 Nilai Tes Menulis Ringkasan Sebelum dan Sesudah Menggunakan Buku Teks Hasil Pengembangan

Jika dibandingkan hasil tes menulis ringkasan sebelum dan setelah menuliskan kembali ringkasan hasil pengembangan, terlihat nilai rata-rata dan selisih nilai rata-rata yang diperoleh oleh mahasiswa yang mengikuti pretest dan posttest tersebut. Untuk lebih jelasnya, perhatikan grafik berikut ini.

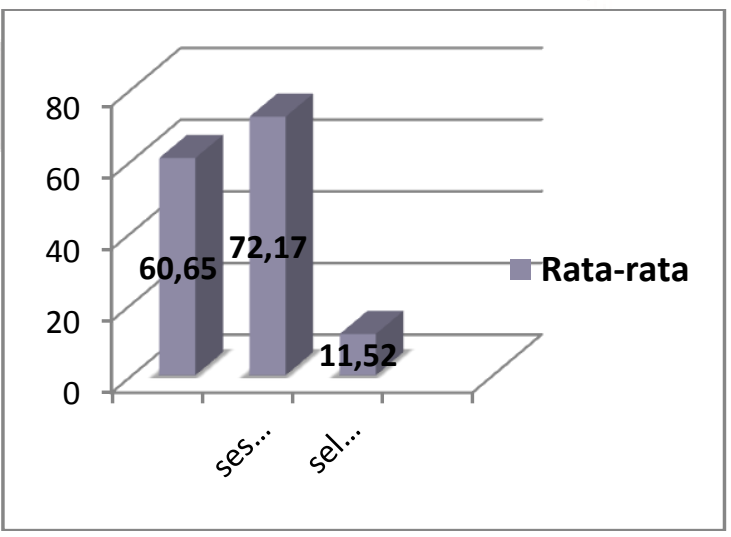




\section{Hasil Pretest dan Posttest Menulis Ikhtisar}

Hasil Pretest dan Posttestmateri menulis ikhtisar pada Program Studi Pendidikan Bahasa, Sastra Indonesia dan Daerah, Fakultas Keguruan dan Ilmu Pendidikan, Universitas Baturaja dapat dilihat pada tabel 2 berikut ini.

Tabel 2 Nilai Pretest dan Posttest Materi Menulis Ikhtisar

\begin{tabular}{|c|c|c|c|}
\hline \multirow{2}{*}{ No. } & \multirow{2}{*}{$\begin{array}{c}\text { Nama } \\
\text { Mahasiswa }\end{array}$} & \multicolumn{2}{|c|}{ Nilai } \\
\hline & & Pretest & Posttest \\
\hline 1. & APR & 67 & 87 \\
\hline 2. & HNS & 53 & 60 \\
\hline 3. & LSH & 67 & 80 \\
\hline 4. & YIS & 67 & 73 \\
\hline 5. & $\mathrm{AAC}$ & 47 & 53 \\
\hline 6. & $\mathrm{NAO}$ & 53 & 73 \\
\hline 7. & PAR & 53 & 67 \\
\hline 8. & SUN & 33 & 53 \\
\hline 9. & ONS & 60 & 87 \\
\hline 10. & $\mathrm{AKS}$ & 67 & 80 \\
\hline 11. & $\mathrm{AAD}$ & 20 & 53 \\
\hline 12. & MSA & 67 & 73 \\
\hline 13. & ERD & 67 & 80 \\
\hline 14. & SFI & 67 & 80 \\
\hline 15. & NZP & 67 & 73 \\
\hline 16. & GOP & 40 & 53 \\
\hline 17. & HAR & 67 & 80 \\
\hline 18. & MSM & 67 & 87 \\
\hline 19. & BIR & 67 & 80 \\
\hline 20. & RAS & 67 & 73 \\
\hline 21. & NAS & 33 & 73 \\
\hline 22. & MMH & 53 & 67 \\
\hline 23. & MAS & 67 & 80 \\
\hline & Jumlah & 1316 & 1665 \\
\hline & Rata-rata & 57,22 & 72,39 \\
\hline & Selisih & & \\
\hline
\end{tabular}

Berdasarkan data nilai pretest dan posttest yang diperoleh dalam tes materi menulis ikhtisar yang terdapat pada tabel tersebut, secara keseluruhan terlihat bahwa nilai yang diperoleh mahasiswa mengalami peningkatan. Nilai tertinggi pada kegiatan pretest sebelum mahasiswa menggunakan buku teks menulis ikhtisar adalah 67. Setelah mahasiswa diberikan penjelasan dan menggunakan buku teks Mari Menulis hasil pengembangan, nilai tertinggi mahasiswa mencapai 87. Sebaliknya, nilai terendah sebelum mahasiswa menggunakan buku teks Mari Menulis hanya mencapai nilai 20 dan setelah diberikan buku teks hasil pengembangan nilainya adalah 53 . Adapun perincian perolehan nilai mahasiswa tersebut dapat digambarkan pada grafik berikut ini.

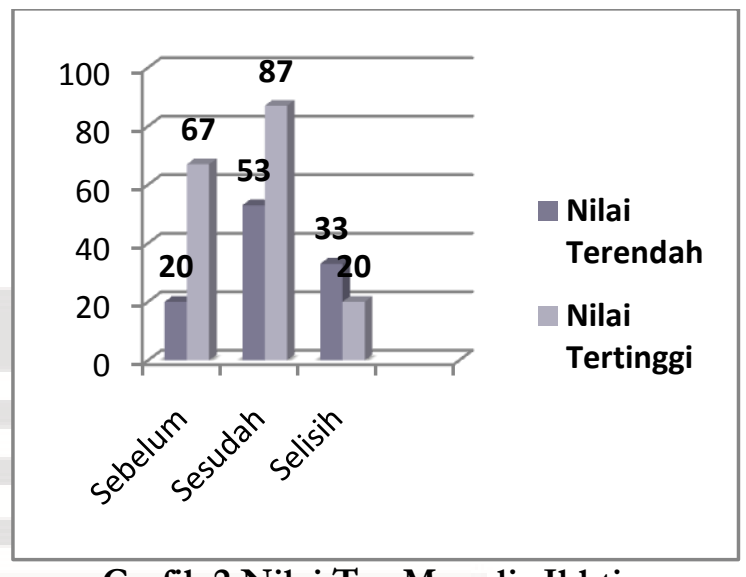

\section{Grafik 2 Nilai Tes Menulis Ikhtisar Sebelum dan Sesudah Menggunakan Buku Teks Hasil Pengembangan}

Jika dibandingkan hasil tes menulis ikhtisar sebelum dan setelah menggunakan bahan ajar hasil pengembangan, terlihat nilai rata-rata dan selisih nilai rata-rata yang diperoleh oleh mahasiswa yang mengikuti pretest dan posttest tersebut. Untuk lebih jelasnya, perhatikan grafik berikut ini.

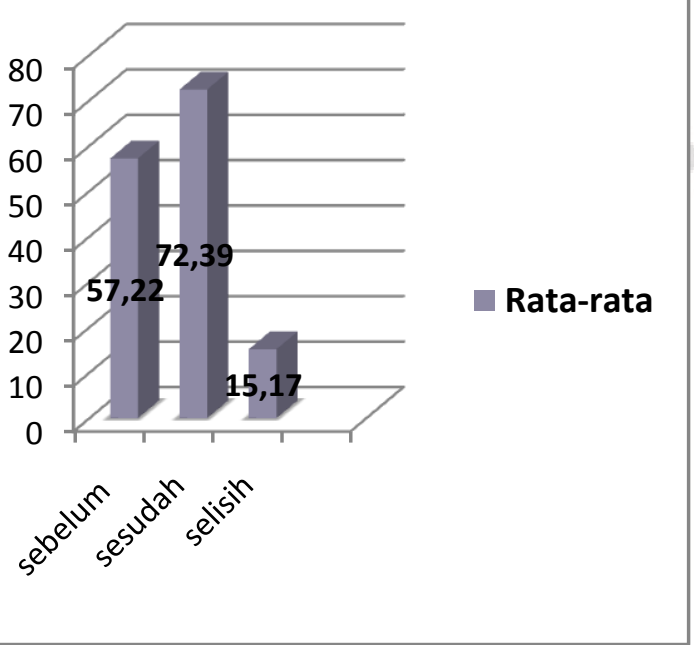

\section{Hasil Uji Statistik \\ Hasil Uji Statistik Deskriptif}

Uji statistik ini dilakukan untuk memperoleh informasi tentang ada atau tidak perbedaan tingkat kemampuan dan pemahaman menulis mahasiswa sebelum dan setelah menggunakan bahan ajar hasil 
pengembangan. Uji statistik yang dilakukan adalah uji statistik menggunakan SPSS 16 melalui uji $t$.

Berdasarkan data nilai tes mahasiswa yang diperoleh dari tes menulis ringkasan untuk menilai kemampuan mahasiswa dalam menuliskan ringkasan dengan benar, perhitungan statistik deskriptif ringkasan dapat digambarkan pada tabel 3 berikut ini.

Tabel 3 Statistik Deskriptif dari Nilai Pretest dan Posttest Menulis Ringkasan

\begin{tabular}{|l|c|c|c|c|c|}
\hline & N & Min & Max & Mean & $\begin{array}{l}\text { Std. } \\
\text { Dev }\end{array}$ \\
\hline & & & & & \\
\hline Pretest & 23 & 50 & 80 & 60.65 & 9.208 \\
\hline Posttest & 23 & 60 & 85 & 72.17 & 7.661 \\
\hline $\begin{array}{l}\text { Valid N } \\
\text { (listwise) }\end{array}$ & 23 & & & & \\
\hline
\end{tabular}

Tabel di atas menunjukkan hasil dari nilai pretest dan posttest pada menulis ringkasan. Nilai terendah pada pretest adalah 50 dan nilai tertinggi adalah 80 sedangkan nilai terendah pada posttest menulis ringkasan adalah 60 dan nilai tertinggi adalah 85 . Nilai rata-rata (mean) pada pretest menulis ringkasan adalah 60,65 dengan standar deviasi 9,208. Sedangkan nilai rata-rata (mean) pada posttest menulis ringkasan 72,17 dengan standar deviasi 7,661.

Sementara itu, untuk mengetahui apakah informasi data yang didapat normal atau tidak, peneliti melakukan uji normalitas. Uji normalitas pada penelitian ini menggunakan Kolmogorov-Smirnov Test melalui program SPSS 16.

Adapun hasil uji normalitas ringkasan untuk mendeskripsikan menulis ringkasan yang diberikan pada mahasiswa Program Studi Pendidikan Bahasa, Sastra Indonesia dan Daerah Fakultas Keguruan dan Ilmu Pendidikan (FKIP), Universitas Baturaja, dapat dilihat pada tabel 3 berikut ini.
Tabel 3

Uji Normalitas Pada Menulis Ringkasan dengan Menggunakan One-Sample Kolmogorov-Sminov Test

\begin{tabular}{|ll|l|c|}
\hline & & Pretest & Posttest \\
\hline $\mathrm{N}$ & & 23 & 23 \\
Normal & Mean & 60.65 & 72.17 \\
Parameters & Std. & & \\
& Deviation & & \\
& Most Extreme Absolute & 224 & 7.661 \\
Difference & Positive & .224 & .166 \\
s & Negative & -.149 & -.166 \\
Kolmogorov-Smirnov Z & 1.075 & .794 \\
Asymp. Sig. (2-tailed) & 198 & .553 \\
\hline
\end{tabular}

Berdasarkan tabel di atas, data pretest pada menulis ringkasan menunjukkan sig (2tailed) yaitu 0,198. Angka 0,198 lebih besar dari 0,05, dapat disimpulkan bahwa data pretest pada menulis ringkasan adalah normal. Begitu juga pada data posttest menulis ringkasan yang menunjukan sig (2-tailed) yaitu 0,553. Angka 0,553 lebih besar daripada 0,05, maka dapat disimpulkan bahwa data posttest pada menulis ringkasan adalah normal. Untuk lebih jelasnya normalitas data nilai hasil pretest dan posttest menulis ringkasan dapat dilihat pada kurva 1 dan kurva 2 berikut ini.

\section{Kurva 1}

\section{Kurva Uji Normalitas Pretest Menulis} Ringkasan

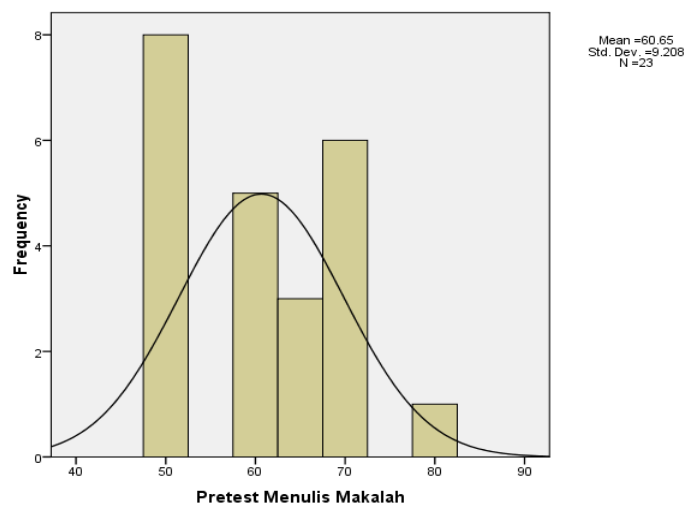

Berdasarkan kurva di atas data nilai pretest pada menulis ringkasan menunjukkan normalitas. 
Kurva 2

Kurva Uji Normalitas Posttest Menulis Ringkasan

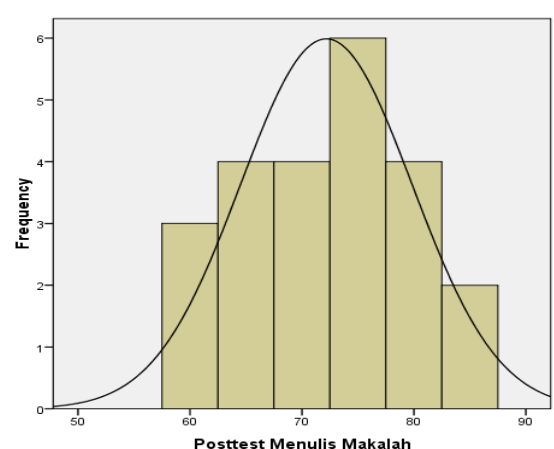

menggunakan Kolmogorov-Smirnov Test melalui program SPSS 16. Adapun hasil uji normalitas menulis ikhtisar untuk mendeskripsikan pengklasifikasian menulis ikhtisar dan analisisnya yang diberikan pada mahasiswa Program Studi Pendidikan Bahasa, Sastra Indonesia dan Daerah Fakultas Keguruan dan Ilmu Pendidikan (FKIP), Universitas Baturaja, dapat dilihat pada tabel 5 berikut ini.

Tabel 5

Uji Normalitas Pada Menulis Ikhtisar Menggunakan One-Sample KolmogorovSmirnov Test

Berdasarkan kurva di atas data nilai posttest pada menulis ringkasan menunjukkan normalitas.

\section{Hasil Uji Statistik Materi Aspek Menulis Ikhtisar}

Berdasarkan data nilai tes mahasiswa yang diperoleh dari tes menulis ikhtisar untuk menilai kemampuan mahasiswa dalam mengklasifikasikan jenis menulis ikhtisar dapat digambarkan pada tabel 4 berikut ini.

Tabel 4. Statistik Deskriptif dari Nilai Pretest dan Posttest Menulis Ikhtisar

\begin{tabular}{|l|c|c|c|c|c|}
\hline & N & Min & Max & Mean & Std. Dev \\
\hline Pretest & 23 & 40 & 70 & 60.65 & 8.161 \\
\hline Posttest & 23 & 50 & 85 & 72.17 & 9.394 \\
\hline $\begin{array}{l}\text { Valid N } \\
\text { (listwise) }\end{array}$ & 23 & & & & \\
\hline
\end{tabular}

Tabel di atas menunjukkan hasil dari nilai pretest dan posttest pada menulis ikhtisar. Nilai terendah pada pretest adalah 40 dan nilai tertinggi adalah 70 sedangkan nilai terendah pada posttest menulis ikhtisar adalah 50 dan nilai tertinggi adalah 85 . Nilai rata-rata (mean) pada pretest menulis ikhtisar 60,65 dengan standar deviasi 8,161 sedangkan nilai rata-rata (mean) pada posttest menulis ikhtisar 72,17 dengan standar deviasi 9,394.

Sementara itu, untuk mengetahui apakah informasi data yang didapat normal atau tidak, peneliti melakukan uji normalitas. Uji normalitas pada penelitian ini

\begin{tabular}{|ll|c|c|}
\hline & Pretest & Posttest \\
\hline \multicolumn{2}{|c|}{$\mathrm{N}$} & 23 & 23 \\
Normal & Mean & 60.65 & 72.17 \\
Paramete & Std. & & \\
rs $^{a}$ & Deviation & 8.161 & 9.394 \\
Most & Absolute & .251 & .189 \\
Extreme & Positive & .141 & .125 \\
Differenc & Negative & -.251 & -.189 \\
es & Nolmogonv-Smirnov Z & 1.203 & .906 \\
Kosymp. Sig. (2-tailed) & .111 & .384 \\
\hline
\end{tabular}

Berdasarkan tabel di atas, data pretest pada menulis ikhtisar menunjukkan sig (2tailed) yaitu 0,111 . Angka 0,111 lebih besar dari 0,05, dapat disimpulkan bahwa data pretest pada menulis ikhtisar adalah normal. Begitu juga pada data posttest menulis ikhtisar yang menunjukan sig (2-tailed) yaitu 0,384. Angka 0,384 lebih besar daripada 0,05, dapat disimpulkan bahwa data posttest pada menulis ikhtisar adalah normal.

Untuk lebih jelasnya normalitas data nilai hasil pretest dan posttest menulis ikhtisar dapat dilihat pada kurva 3 dan kurva 4 berikut ini. 
Kurva 3

Kurva Uji Normalitas Pretest Menulis Ikhtisar

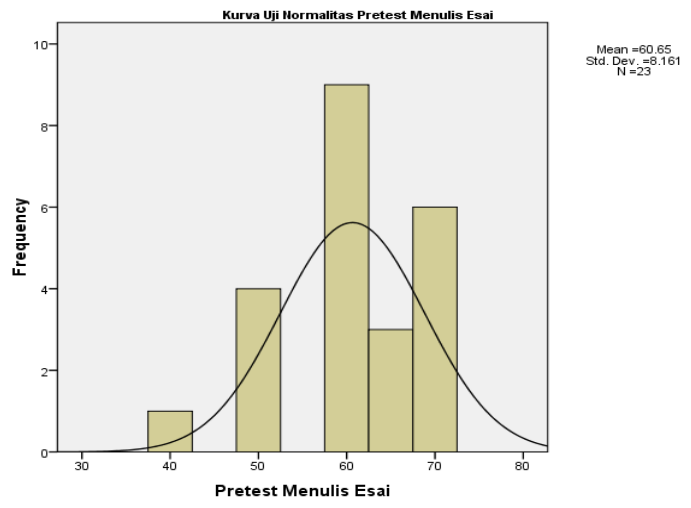

Berdasarkan kurva di atas data nilai pretest pada menulis ikhtisar menunjukkan normalitas.

\section{Kurva 4}

Kurva Uji Normalitas Posttest Menulis Ikhtisar

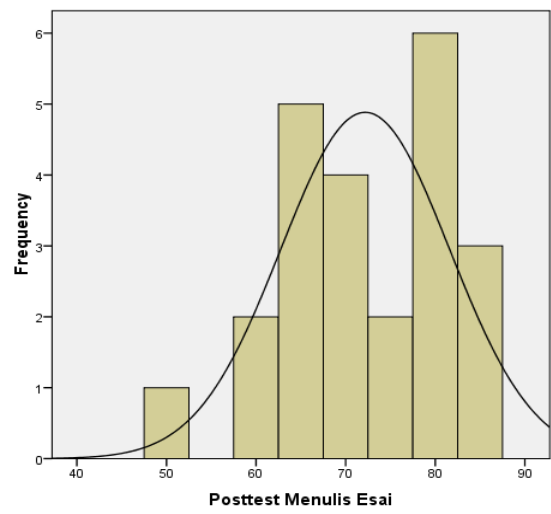

Berdasarkan kurva di atas data nilai posttest pada menulis ikhtisar menunjukkan normalitas.

\section{Kesimpulan}

Berdasarkan hasil penelitian dan pembahasan yang dikemukakan dalam bab sebelumnya, dapat ditarik beberapa kesimpulan sebagai berikut. Pertama, mahasiswa semester 2 Program Studi Pendidikan Bahasa, Sastra Indonesia dan Daerah, Fakultas Keguruan dan Ilmu pendidikan (FKIP) Universitas Baturaja memiliki kebutuhan yang beragam tentang bahan ajar Menulis Ringkasan dan Ikbtisar. Kebutuhan tersebut berkaitan dengan aspek isi dan aspek fisik bahan ajar. Dari isinya, mahasiswa membutuhkan bahan ajar yang menyenangkan dan mudah dipahami untuk dapat meningkatkan kemampuan menulis. Dari aspek fisik bahan ajar, mahasiswa membutuhkan bahan ajar yang menarik dari segi warna dan gambar yang memotivasi. Kedua, buku teks yang dirancang dalam penelitian ini memiliki spesifikasi buku teks yang: (1) menyajikan petunjuk atau skenario kegiatan pembelajaran yang jelas, (2) menyajikan materi yang sesuai dengan kebutuhan mahasiswa, (3) menyajikan contohcontoh yang memudahkan mahasiswa dalam memahami materi yang disajikan, menyajikan latar yang berwarna untuk bagian contoh dan rangkuman serta glosarium, dan (5) menyajikan komponen buku teks yang terdiri dari judul, kompetensi dasar (KD), indikator, tujuan pembelajaran, materi, rangkuman, latihan, penilaian, glosarium, dan daftar pustaka. Ketiga, Buku teks hasil pengembangan ini dinyatakan layak digunakan dalam kegiatan pembelajaran di Program Studi Pendidikan Bahasa, Sastra Indonesia dan Daerah, Fakultas Keguruan dan Ilmu pendidikan (FKIP) Universitas Baturaja dan di perguruan tinggi lain yang memiliki karakteristik dan kebutuhan yang relatif sama dengan universitas tempat bahan ajar ini diujicobakan. Hal ini didasarkan pada hasil validasi ahli kelayakan isi/materi, ahli kebahasaan, ahli penyajian materi, dan ahli kegrafikaan serta hasil uji coba lapangan terbatas. Keempat, buku teks hasil pengembangan ini memiliki pengaruh yang potensial terhadap peningkatan kemampuan mahasiswa terhadap hasil belajar menulis ringkasan dan ikhtisar melalui pemberian contoh-contoh untuk memudahkan mahasiswa memahami materi dan pemberian latihan untuk meningkatkan hasil belajar mahasiswa. Peningkatan kemampuan mahasiswa tersebut dapat dilihat dari hasil nilai rata-rata sebelum mahasiswa menggunakan buku teks hasil pengembangan dan hasil nilai rata-rata tersebut mengalami peningkatan setelah mahasiswa menggunakan buku teks hasil pengembangan. 


\section{Daftar Pustaka}

Ahmadi, Abu. 2010. Konstruksi Pengembangan Pembelajaran. Jakarta: Prestasi Pustaka.

Alex. 2011. Babasa Indonesia Untuk Perguruan Tinggi. Jakarta: Kencana.

Desrina, Ilhami, Peningkatan Keterampilan Menulis Ringkasan Melalui Model Pembelajaran Kooperatif Tipe Jigsaw Siswa Kelas VIII 7 SMP Negeri 1 Batusangkar. Jurnal Bahasa, Sastra dan Pembelajaran, Vol. 1, No. 3, Oktober 2013, h. 48.

Husnul, Ade. 2010. Cermat Menulis Ikhtisar dan Ringkasan Isi Buku. Bogor: Quadra.

Jabrohim. 2009. Cara Menulis Kreatif. Yogyakarta: Pustaka Pelajar.

Mbulu, J. dan Suhartono. 2004. Pengembangan Bahan Ajar. Malang: Elang Mas.

Nurgiyantoro, Burhan. 2001. Menulis Secara Populer. Jakarta: Pustaka Jaya.

Prastowo, Andi. 2011. Panduan Kreatif Membuat Baban Ajar Inovatif. Yogyakarta: Diva Press.

Setiawan, Denny. 2007. Pengembangan Baban Ajar. Jakarta: Universitas Terbuka.

Simulyasi, Nugraheti, Menulis Manuskrif Jurnal Ilmiah, Strategi Synergetic Teaching: Jurnal Primary Program Studi Pendidikan Guru Sekolah Dasar Fakultas Keguruan dan Ilmu Pendidikan Universitas Riau, Vol. 4, No. 1, April 2015, h. 65.

Syahid, A. 2003. Pengembangan Bahan Ajar Mata Kuliah Rancangan Pembelajaran dengan Menerapkan Model Elaborasi. Tesis, Tidak Diterbitkan. UM: PPS.

Yunus, M. 2002. "Surat Menyurat Dinas" dalam Keterampilan Dasar Menulis Modul. Jakarta: Pusat Penerbitan UT. 